\title{
Fire recurrence and emergency post-fire management influence seedling recruitment and growth by altering plant interactions in fire-prone ecosystems
}

\author{
Angela Taboada*, Reyes Tárrega, Elena Marcos, Luz Valbuena, Susana Suárez-Seoane, Leonor Calvo \\ Area of Ecology, University of León, E-24071 León, Spain \\ Institute of Environmental Research (IMA), University of León, E-24071 León, Spain
}

\section{A R T I C L E I N F O}

\section{Keywords:}

Competition

Facilitation

Large fires

Natural regeneration

Pinus pinaster

Post-fire restoration

\begin{abstract}
A B S T R A C T
Projections of future wildfire regimes forecast an increased frequency of large high-severity fires that create very harsh environmental conditions and constitute a challenge to post-fire ecosystem regeneration. Under these new circumstances, better knowledge of the plant interaction mechanisms underlying post-fire seedling establishment success would aid restoration management to achieve the intended targets. We evaluated the combined effect of recurrent large stand-replacing fires and conventional post-fire restoration activities (salvage logging after a single large fire, and direct seeding and linear subsoiling plus seedling planting after two subsequent large fires) on tree seedling recruitment and performance (development, annual growth, and biomass) in the early stages of succession in fire-prone maritime pine (Pinus pinaster Ait.) ecosystems. We quantified plant facilitative/competitive interactions between naturally recruited pine seedlings, neighbouring seedlings and potential nurse shrubs with different post-fire regeneration strategies (obligate seeders $v s$ resprouters), by computing the relative interaction index (RII). The results evidenced that fire recurrence altered plant species composition and conditioned initial pine seedling recruitment and establishment, prevailing over the expected negative impact of salvage logging and positive impact of seeding. Seedling recruitment was sufficient to ensure natural tree regeneration after a single fire event and undermined by repeated fires. Both delaying burned timber removal during salvage logging operations and retaining immature dead trees without commercial value onsite in subsoiled stands enhanced seedling recruitment via facilitative interactions. Higher seedling growth and height under shrubs than in open ground resulted in lower aerial and root biomass, indicating elongation in response to shade, and net competition for resources. Inter-specific competition between naturally regenerated seedlings and shrubs was aggravated by intra-specific competition with neighbouring seedlings and by mechanical site preparation in subsoiled stands. All in all, post-burn increased soil fertility most likely counterbalanced the environmental stress created by fire, shifting the net outcome of plant interactions from positive (facilitation) to negative (competition). We recommend alternative post-fire management actions that decrease plant competition and take advantage of facilitation by residual burned wood, to ultimately accelerate ecosystem recovery after large stand-replacing fires.
\end{abstract}

\section{Introduction}

Positive interactions (i.e., facilitation) between neighbouring plants are common in harsh physical environments, such as arid/semi-arid areas, playing a key role in species distribution and in community dynamics and composition (e.g., Callaway et al., 2002; Maestre et al., 2003; Tewksbury and Lloyd, 2001; but see Maestre and Cortina, 2004; Maestre et al., 2005). Benefactor plants improve recruitment and performance of beneficiary ones, through numerous processes like nutrient accumulation, microclimate amelioration, and herbivory protection (Gómez-Aparicio et al., 2005, 2008; Maestre et al., 2003). Facilitation generally prevails under high abiotic stress or disturbance (Bertness and Callaway, 1994); but the net outcome of facilitative/competitive interactions acting simultaneously is the result of multiple factors (reviewed by Maestre et al., 2009), including the identity and life-strategies of the interacting species (Gavinet et al., 2016; Gómez-Aparicio, 2009; Gómez-Aparicio et al., 2008; Prévosto et al., 2012; Schöb et al.,

\footnotetext{
* Corresponding author at: Area of Ecology, Department of Biodiversity and Environmental Research, University of León, Campus Vegazana s/n, E-24071 León, Spain.

Email address: angela.taboada@unileon.es (A. Taboada)
} 
2013) and the nature and degree of the environmental stress (Maestre et al., 2003; Pugnaire and Luque, 2001).

In extremely degraded and highly disturbed environments like fire-prone ecosystems, plant facilitation mechanisms can act as the essential basis of restoration techniques to accelerate vegetation recovery and achieve the intended targets (Brooker et al., 2008; Gómez-Aparicio, 2009; Padilla and Pugnaire, 2006). To date, much research (mostly experimental studies) has demonstrated the facilitative effects of naturally-occurring nurse plants (shrubs, in particular; Gómez-Aparicio, 2009; Gómez-Aparicio et al., 2005; Siles et al., 2008, 2010) and inanimate objects (e.g., dead logs and branches; Beghin et al., 2010; Castro et al., 2011; Marañón-Jiménez et al., 2013) in ecosystem regeneration after a single fire event (see reviews by Brooker et al., 2008; Padilla and Pugnaire, 2006). Yet, conventional post-fire management operations like salvage logging (i.e., the removal of burned trees and remaining woody debris) and mechanical site preparation with heavy machinery prior to seeding or planting of seedlings are widely implemented by forest administrations (see e.g., Beghin et al., 2010; Castro et al., 2011; Espelta et al., 2003; Leverkus et al., 2012), overlooking the advantages of alternative facilitation-based restoration practices.

Predictions of future fire regimes forecast an increase in the recurrence and severity of wildfires under a warmer and drier climate (Doblas-Miranda et al., 2014; Moreira et al., 2011; Pausas and Vallejo, 1999; Pausas et al., 2008), specifically in areas with high productivity (Pausas and Paula, 2012), together with an increase in the number of large fires that burn thousands of hectares (Moreira et al., 2011; see also Pausas and Fernández-Muñoz, 2012) and have more adverse ecological effects (Moreira et al., 2011; Pausas et al., 2008; and references therein). Ecosystem restoration after such large stand-replacing fires constitutes a new challenge for forest managers, as these fires (1) create very severe environmental conditions (e.g., high soil erosion and solar radiation), (2) entail the extensive destruction of the vegetation and, therefore, the loss of potential nurse plants, and (3) often cause major shifts in plant dominance and community structure and composition (Pausas et al., 2008; Puerta-Piñero et al., 2012; Rodrigo et al., 2004; Torres et al., 2016). Frequent large high-severity fires further result in limited or failed natural tree regeneration (Pausas et al., 2008; Tapias et al., 2001) and in the medium-term massive proliferation of pioneer shrubs (Baeza et al., 2007; Retana et al., 2002) generating homogeneous landscapes with high fuel load accumulation (Loepfe et al., 2010; Moreira et al., 2011; Pausas and Fernández-Muñoz, 2012). Whether these new circumstances created by recurrent large fires alter plant facilitation mechanisms and condition the application of alternative restoration practices is presently poorly understood.

In this study, we evaluated the joint effects of recurrent large stand-replacing fires and post-fire restoration activities on tree seedling recruitment and performance (development, annual growth, and biomass), mediated by changes in the regeneration strategies of potential nurse plants after fire: (1) obligate seeder shrubs with fire-stimulated recruitment, slow post-fire recovery and low competitive abilities (Pausas and Vallejo, 1999), and (2) resprouter shrubs highly-tolerant to short between-fire intervals, capable of fast post-fire regeneration and with high competitive abilities (Calvo et al., 2012; Keeley, 1986; Pausas and Vallejo, 1999; Valdecantos et al., 2008). We intended to determine the efficiency of conventional restoration operations applied by forest managers immediately following fire (i.e., salvage logging after a single large fire, and direct seeding and linear subsoiling plus seedling planting after two subsequent large fires) in helping the natural regeneration of fire-prone ecosystems at early stages of succession (i.e., active restoration; Moreira et al., 2012; see e.g., Ammer and Mosandl, 2007; Beghin et al., 2010; Moreira et al., 2009). We selected maritime pine (Pinus pinaster Ait.) forests threatened by increasing wildfire frequency (Fernandes and Rigolot, 2007), like other Mediterranean serotinous pine forests (Espelta et al., 2008; Eugenio et al., 2006), as the model ecosystem. $P$. pinaster is a fire-dependent obligate seeder species that relies mostly on the aerial seed bank for post-fire recovery (Calvo et al., 2013; Fernandes and Rigolot, 2007). Solar radiation is an important environmental factor determining maritime pine seed germination, seedling survival, and early seedling development (Fernandes et al., 2017; Rodríguez et al., 2008; Rodríguez-García and Bravo, 2013; Rodríguez-García et al., 2011; Ruano et al., 2009).

We expected that (i) under the stressful conditions after a single large stand-replacing fire the regrowth of potential nurse plants (obligate seeder shrubs in particular) will protect pine seedlings against the harsh environment, resulting in net facilitation and improved seedling performance (Castro et al., 2004; Fernandes et al., 2017; Rodríguez-García et al., 2011; Ruano et al., 2009); (ii) post-fire salvage logging after a large fire will eliminate potential nurse objects (burned tree trunks, branches, logs, and snags), increase soil compaction, and damage the soil seed bank, delaying facilitative interactions (basically, between obligate seeder shrubs and pine seedlings), and lessening seedling performance (Castro et al., 2011; Marañón-Jiménez et al., 2013); (iii) the occurrence of two subsequent large high-severity fires will favour highly-adapted resprouter shrubs over obligate seeder shrubs (Calvo et al., 2012; Keeley, 1986; Pausas and Vallejo, 1999), shifting plant-plant interactions from facilitative to competitive ones, and reducing seedling performance (Gavinet et al., 2016); (iv) mechanical site preparation prior to planting of seedlings after recurrent fires will decrease soil resistance, improve water and air transport, and promote the development of a deep root system of the planted trees, reducing competition and enhancing seedling performance (Espelta et al., 2003; but see Löf et al., 2012).

\section{Materials and methods}

\subsection{Study site and population}

The study site is located in Sierra del Teleno (NW Spain; $42^{\circ} 15^{\prime} 34^{\prime \prime} \mathrm{N} / 06^{\circ} 12^{\prime} 13^{\prime \prime} \mathrm{W}$; 915-1200 m a.s.l.; 10\% average slope), a mountain range where wildfires have frequently occurred [172 small ( $<500 \mathrm{ha}$ ) and 5 large ( $>500 \mathrm{ha}$ ) fires recorded in 1974-2007 that burned $14,243 \mathrm{ha}$, typically caused by dry spring-summer storms (Santamaría, 2015). From 1978 to 2014, the number of fires that occurred in the study site ranged from 1 to 4 (four fire recurrences identified from visual interpretation of 75 Landsat images and validation with official fire reports; Fernández-García et al., 2015). The climate is Mediterranean with mean annual precipitation between 650 and $900 \mathrm{~mm}$, mean annual temperature of $10^{\circ} \mathrm{C}$, and $2-3$ months of summer drought. Soils are Cambisols, very sandy and acidic $(\mathrm{pH}=4.66 \pm 0.25)$ with low organic matter content (Calvo et al., 2008). The landscape is dominated by pine forests (73\% P. pinaster, $3 \%$ P. nigra Arn., 2\% P. sylvestris L.), deciduous forests (7\% Quercus ilex L., $5 \%$ Q. pyrenaica Willd.), and shrublands (10\%, mainly Erica australis L. and Pterospartum tridentatum (L.) Willk., with Halimium lasianthum spp. alyssoides (Lam.) Greuter, and Calluna vulgaris (L.) Hull).

The study site encompasses (Fig. 1):

(1) 8221 ha affected by a single fire event: a large high-severity man-induced wildfire that burned 11,891 ha $(72 \%$ covered by $P$. pinaster natural forests for timber production with a mean tree density of 906 individuals ha ${ }^{-1}$ and a mean basal trunk diameter of $22.31 \mathrm{~cm}$, and with a shrubby understorey dominated by the resprouter shrubs E. australis and $P$. tridentatum) in 19-21 August 2012. The understorey was totally destroyed and the majority of 

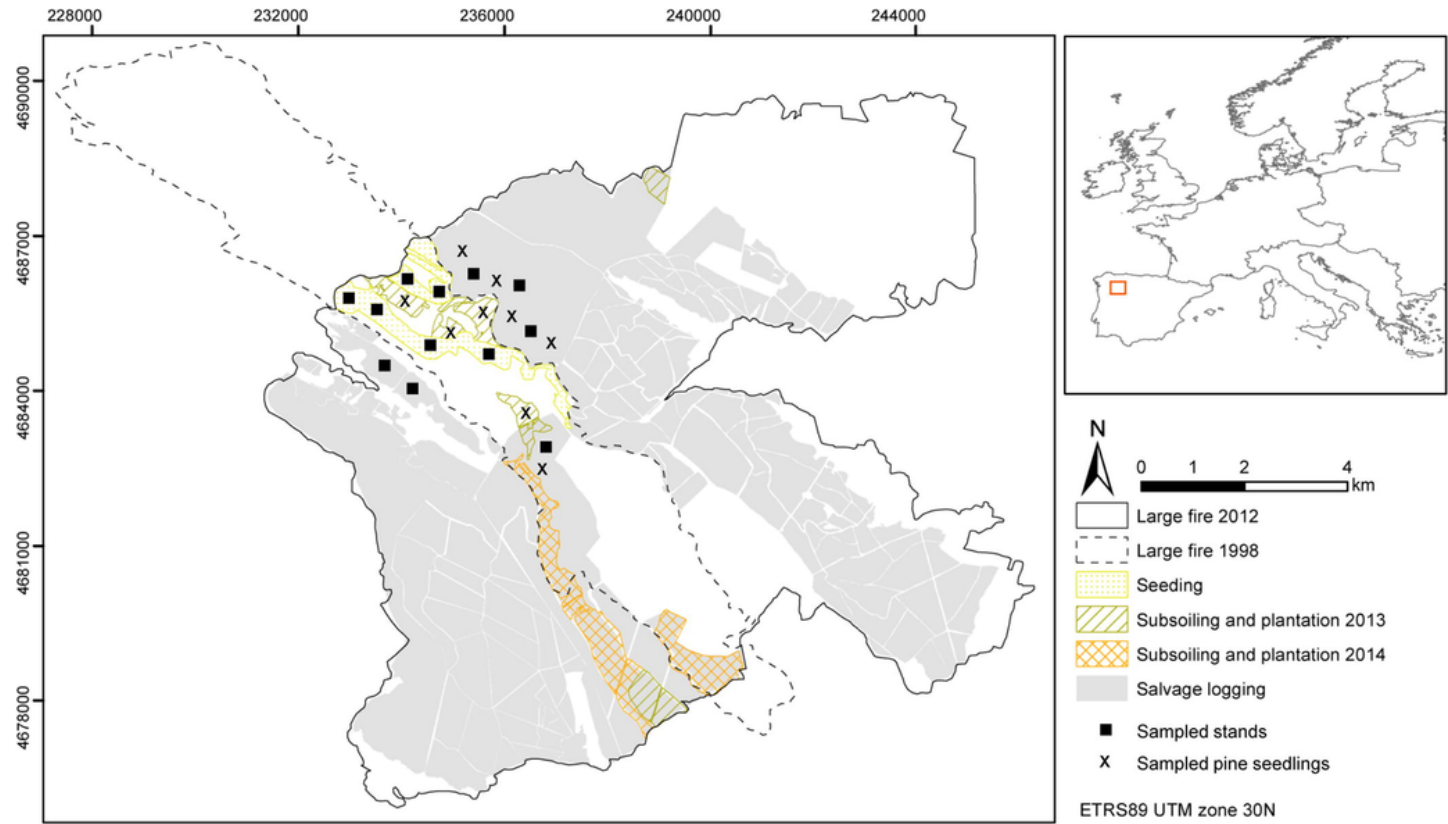

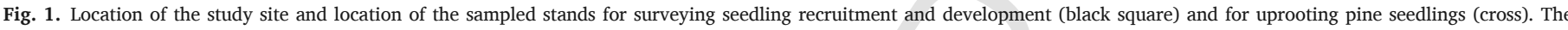
perimeters of the 1998 and 2012 fires and the areas where the post-fire treatments were applied are indicated. See the text and Table 1 for further details.

tree crowns were completely consumed by fire, resulting in landscape homogenisation; and

(2) 1920 ha affected by two fire events: the abovementioned 2012 fire and an earlier large high-severity man-induced wildfire that burned 3670 ha (93\% covered by $P$. pinaster natural forests for timber production with a shrubby understorey dominated by $E$. australis) in 13-14 September 1998. At the time of the 2012 fire, pine trees were $12-14$ years old with a mean density of 12,778 individuals ha ${ }^{-1}$ and a mean basal trunk diameter of $3.7 \mathrm{~cm}$.

The studied $P$. pinaster population is highly adapted to extremely intense crown fires with more than $95 \%$ of the trees bearing serotinous cones that can persist in the canopy bank up to 40 years, and with stored seeds remaining viable for 30 years (Tapias et al., 2004). Seed release is delayed several days after a fire, when optimal post-burn conditions (i.e., high availability of space and nutrients, low competition for water and light, and low predation risk) allow high rates of seed germination and seedling emergence (Hernández-Serrano et al., 2013). In the last decades, however, the post-fire natural regeneration of $P$. pinaster has been undermined by the increased frequency of wildfires, occurring at intervals of less than 10-15 years, the minimum required time for pines to reach reproductive maturity (Pausas et al., 2008; Tapias et al., 2001). Consequently, $P$. pinaster forests show low resilience to recurrent large fires, turning into successional shrublands (Baeza et al., 2007).

\subsection{Post-fire management treatments}

Immediately after the 2012 fire, the regional Forest Service (Government of Castilla and León) implemented a number of emergency post-fire treatments in the burned area to, inter alia, recover timber value, reduce the risk of xylophage infestation [mainly, Ips sexdentatus (Börner, 1776) (Coleoptera, Scolytidae)], facilitate tree regeneration, and complete the recovery of the burned area, which accentuated the landscape homogenisation created by fire, and included (Fig. 1, Table 1, and Supplementary Material):
Table 1

Post-fire restoration treatments implemented in the study site after the 2012 fire. The number of sampled stands and uprooted pine seedlings, and the main seedling characteristics (origin, position, and age) are indicated.

\begin{tabular}{|c|c|c|c|}
\hline 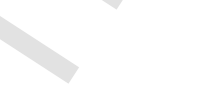 & $\begin{array}{l}\text { Salvage } \\
\text { logging (SL) }\end{array}$ & $\begin{array}{l}\text { Seeding } \\
\text { (SE) }\end{array}$ & $\begin{array}{l}\text { Subsoiling and } \\
\text { seedling } \\
\text { planting (SP) }\end{array}$ \\
\hline $\begin{array}{l}\text { Large-fire regime } \\
\text { (year) }\end{array}$ & 1 fire (2012) & $\begin{array}{l}2 \text { fires } \\
(1998, \\
2012)\end{array}$ & $\begin{array}{l}2 \text { fires (1998, } \\
2012)\end{array}$ \\
\hline $\begin{array}{l}\text { Number of stands } \\
\text { (seedling } \\
\text { recruitment and } \\
\text { development) }\end{array}$ & 6 & 6 & \\
\hline $\begin{array}{l}\text { Number of stands } \\
\text { (seedling annual } \\
\text { growth and } \\
\text { biomass) }\end{array}$ & 5 & & 4 \\
\hline $\begin{array}{l}\text { Origin of uprooted } \\
\text { pine seedlings } \\
\text { (number of } \\
\text { individuals) }\end{array}$ & $\begin{array}{l}\text { Naturally } \\
\text { recruited } \\
(30)\end{array}$ & & $\begin{array}{l}\text { Naturally } \\
\text { recruited (12), } \\
\text { planted (12) }\end{array}$ \\
\hline $\begin{array}{l}\text { Number of uprooted } \\
\text { pine seedlings } \\
\text { (position) }\end{array}$ & $\begin{array}{l}18 \text { (under } \\
\text { shrub), } 12 \\
\text { (open } \\
\text { ground) }\end{array}$ & & $\begin{array}{l}12 \text { (under } \\
\text { shrubs), } 12 \\
\text { (open ground) }\end{array}$ \\
\hline $\begin{array}{l}\text { Age of uprooted } \\
\text { pine seedlings } \\
\text { (number of } \\
\text { individuals) }\end{array}$ & $\begin{array}{l}2 \text { years-old } \\
(24), 3 \text { years- } \\
\text { old }(6)\end{array}$ & & $\begin{array}{l}1 \text { year-old (2), } \\
2 \text { years-old } \\
\text { (19), } 3 \text { years- } \\
\text { old ( } 3 \text { ) }\end{array}$ \\
\hline
\end{tabular}

(1) Salvage logging (SL) of 6961 ha affected by the 2012 fire with adequate natural regeneration (500-3000 pine seedlings ha $^{-1}$ in June 2013) from December 2012 to February 2014. All burned trees were cut and felled by mechanical chain saws, trunks were manually dragged and piled at firebreaks and roads, branches and woody debris were chopped, and all the cut biomass was extracted for timber or fuel production (Supplementary Material). Three years after the 2012 fire, stumps and branches covered $12 \%$ of the surface, herbs $2 \%$, and obligate seeder shrubs (H. lasianthum) $18 \%$ 
(percentage cover values measured on $2342 \times 2$ m surveyed subplots; unpublished data) (Fig. 2A).

(2) Direct seeding (SE) of 245 ha affected by both fires $(1998,2012)$ with limited natural regeneration ( $0-500$ seedlings ha ${ }^{-1}$ ) and stony or rocky steep slopes in April-May 2013. Mature cones were harvested from adjacent unburned $P$. pinaster stands, submitted to progressive drying by sun exposure to release the seeds without damage. No pre-treatments were applied, and seeds were manually scattered by broadcast spreaders [Solo ${ }^{\circ}$ Model 421S Portable Shoulder Spreader; ca. $1.5 \mathrm{~kg} \mathrm{ha}^{-1}$ (Rodríguez et al., 2008)] following contour lines at $2 \mathrm{~m}$ distance before herb regrowth and shrub resprouting (Supplementary Material). Three years after the 2012 fire, standing and fallen burned trees covered $4 \%$, herbs $0.3 \%$, stones $22 \%$, and resprouter shrubs dominated (P. tridentatum, 22\%; E. australis, 14\%) (percentage cover values measured on $152 \times 2 \mathrm{~m}$ surveyed subplots; unpublished data) (Fig. 2B).

(3) Subsoiling and seedling planting (SP) of 550 ha affected by both fires with limited natural regeneration and smooth slopes. Soil preparation was done by bulldozer linear subsoiling in April-June 2013 (Supplementary Material), prior to planting of $P$. pinaster seedlings with similar dimensions (about 20-25 cm height at the time of planting; $1200-1600$ seedlings ha $^{-1}$ ) in October-November 2013 and 2014. Seedlings were grown in nurseries inside forest trays containing 45 cells of $250 \mathrm{~cm}^{3}$ each. The planting space was 3-4 $\mathrm{m}$ within the troughs (bottom; 'SP_trough') of the subsoiled strips and no planting was performed if a naturally recruited seedling existed in the close proximity [i.e., at the ridges (top; 'SP_ridge') of the strips]. Three years after the 2012 fire, standing and fallen burned trees covered $0 \%$ and $6 \%$, and herbs $0 \%$ and $2 \%$ at the troughs and ridges of the strips, respectively; and resprouter shrubs ( $P$. tridentatum, 22\%; E. australis, 11\%) dominated at the ridges while bare soil (98\%) at the troughs (percentage cover values measured on $152 \times 2$ m surveyed subplots; unpublished data) (Fig. 2C).

\subsection{Seedling recruitment and development}

We randomly selected 6 stands of approximately 1 ha in size in which SL and SE were applied after a single and two wildfires, respectively (12 stands in total) (Table 1 ). To minimise variability all the stands were located in nearby areas with similar environmental conditions [i.e., same fire severity (high burn severity values ranging 2.25-3 as measured directly in the field by the Composite Burn Index on a total of 111 30-m-diameter circular plots; Quintano et al., 2015, 2017), altitude, soil type, aspect, and slope] (Fig. 1). We established ten $1 \times 1 \mathrm{~m}$ sampling units along a $20 \mathrm{~m}$-transect per stand to survey plant recovery at 11, 13, 23 and 25 months after the 2012 fire (i.e., in July/September 2013 and 2014). In each sampling unit we counted the total number of $P$. pinaster seedlings alive, measured the height of each seedling to calculate the average height value per unit, and visually estimated the percentage cover of bare soil, all herbaceous and shrub species and $P$. pinaster seedlings. Seedling mortality was insignificant at these stages of succession (no dead seedlings were detected during data acquisition), and even so ca. 33 months after the 2012 fire (number of dead seedlings in $2342 \times 2 \mathrm{~m}$ surveyed subplots $=0.61 \pm 2.33$; unpublished data). We defined the frequency of pine seedling occurrence in each stand as the total number of sampling units where seedlings were present.

\subsection{Seedling annual growth and biomass}

In July 2015 (35 months after the 2012 fire), we conducted a destructive sampling by uprooting a total of 54 randomly selected 1-3 year-old $P$. pinaster seedlings at stands (Table 1 ):

- where SL was applied after a single fire: 6 naturally regenerated seedlings under the canopy of $E$. australis shrubs, 6 under $P$. tridentatum, 6 under $H$. lasianthum [2 years-old (14 individuals), 3 years-old (4)], and 12 in open ground [2 years-old (10 individuals), 3 years-old (2)], at least $50 \mathrm{~cm}$ out of the canopy of any established shrub; and

- where SP was applied after two fires: 12 naturally regenerated seedlings [1 year-old (1 individual), 2 years-old (9), 3 years-old (2)] at the ridges of strips where shrubs proliferated (i.e., under the canopy of E. australis, P. tridentatum, and $H$. lasianthum shrubs), and 12 planted seedlings [1 year-old (1 individual), 2 years-old (10), 3 years-old (1)] at the troughs where vegetation cover was eliminated (i.e., in open ground). The growing period of planted seedlings in the field was $19-20$ months at the time of uprooting.

To minimise variability we collected pine seedlings in nearby stands (5 and 4 stands in which SL and SP were applied, respectively) with similar environmental conditions [i.e., same fire severity (high burn severity values ranging $2.25-3$ as measured directly in the field by the Composite Burn Index on a total of 111 30-m-diameter circular plots; Quintano et al., 2015, 2017), altitude, soil type, aspect, and slope], and in the same sampling area where we established the stands for evaluating seedling recruitment and development (Fig. 1). Similarly to previous studies monitoring the effectiveness of restoration techniques commonly applied by forest managers (e.g., Ammer and Mosandl, 2007; Beghin et al., 2010; Moreira et al., 2009), we compared growth and biomass of naturally recruited seedlings and planted seedlings to determine whether the treatments applied were the best option to enhance natural regeneration after recurrent large fires (i.e., no action versus active restoration; de las Heras et al., 2012; Moreira et al., 2012). Seedling sampling was not conducted at SE stands, since there were no seedlings growing in open interspaces without potential nurse shrub cover or potential nurse inanimate objects (mainly rocks and stones).
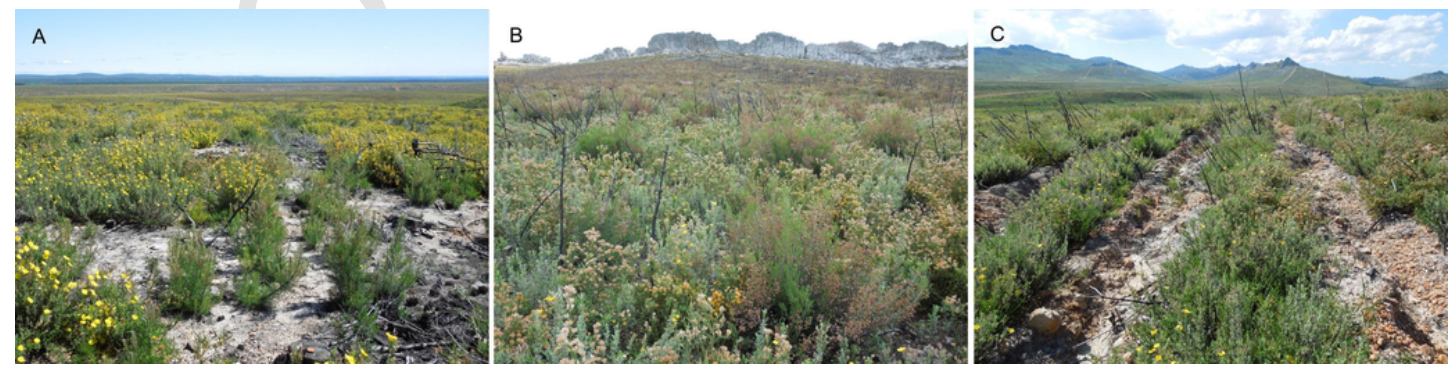

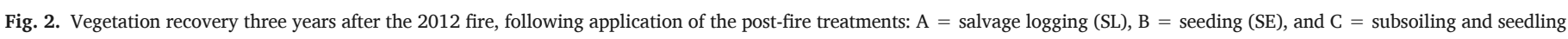
planting (SP). 
For each seedling, we recorded in the field: the distance to the closest shrub, the identity of the closest shrub, the maximum height and diameter of the shrubs at $<50 \mathrm{~cm}$ distance, and the number of neighbouring pine seedlings in a $50 \mathrm{~cm}$-radius. In the laboratory, we determined: the age of each seedling estimated as the number of whorls (Tapias et al., 2001), height, growth in years 1, 2, and 3, estimated as the length of stem between whorls of leaves, and aerial and root biomass. Biomass was measured as dry weight after oven-drying seedling tissue at $45^{\circ} \mathrm{C}$ to constant weight for at least $48 \mathrm{~h}$.

\subsection{Data analysis}

All data analyses were carried out with R software, version 3.1.1 (R Core Team, 2014) using the 'stats', 'nlme' (Pinheiro et al., 2014) and 'MASS' (Venables and Ripley, 2002) packages.

We fitted linear mixed (LMM) and generalised linear mixed (GLMM) models to test the joint effects of fire recurrence and the post-fire treatments (i.e., SL after a single fire, and SE after two fires) on: (1) the total number of pine seedlings alive and (2) the frequency of seedling occurrence in each stand (Poisson error distribution); (3) the average seedling height (Gaussian error distribution), and (4) the percentage of seedling cover (quasi-Poisson error distribution) in each sampling unit. The predictor variables (fixed factors) were time since the 2012 fire $(11,13,23$, and 25 months), post-fire treatment (SL and SE) and their interaction. The interaction term was retained in the models only when significant. The identity of the stands and the identity of the sampling units nested within each stand were included in the first and second set of models as a random factor, respectively. We also fitted equivalent LMMs and GLMMs to examine the impact of the understorey vegetation recovered after the post-fire treatments (predictor variables: percentage cover of herbs, P. tridentatum, E. australis and H. lasianthum) on the above mentioned four response variables.

We fitted linear models (LMs) to evaluate the effects of pine seedling age (1, 2, and 3 years), the post-fire treatment (SL after a single fire, SP_ridge, and SP_trough after two fires), the number of neighbouring seedlings, and the distance to the closest shrub on: (1) pine seedling growth in years 1, 2 and 3, (2) height, (3) aerial and (4) root dry weight, and (5) root/aerial dry weight ratio (Gaussian error distribution). Model predictions were obtained for the most frequent seedling age (2-years-old), the minimum (0) and maximum (4) number of neighbouring seedlings, the minimum $(0 \mathrm{~cm})$ and maximum $(170 \mathrm{~cm})$ distance values to the closest shrub, and the post-fire treatments. For those seedlings growing at $<50 \mathrm{~cm}$ from the closest shrub, we also tested the influence of shrub characteristics [maximum height and diameter, and species identity ( $P$. tridentatum, $E$. australis, and $H$. lasianthum)] on seedling annual growth, height, aerial and root dry weight, and root/aerial dry weight ratio, by fitting analogous LMs. To avoid collinearity, only uncorrelated variables (Spearman's rank correlation coefficient $-0.7<\rho<0.7$ ) that resulted in simple LMs with $\mathrm{p}<0.1$ and highest adjusted $\mathrm{R}^{2}$ values were considered in the multiple LMs. We initially used the Akaike's information criterion (AIC) to compare the fit of LMMs with the identity of the individual seedlings as random factor, and the fit of generalised least squares (GLS) models without the random factor using restricted maximum likelihood estimation (REML) procedures, by means of the 'anova()' and ' $\mathrm{gls}($ )' functions. Models without the random factor were the most parsimonious ones and, therefore, only LMs are reported.

Additionally, to estimate the net outcome of shrub interactions with pine seedlings, we calculated the relative interaction index [RII; Armas et al. (2004)] for the model predicted values of seedling performance (i.e., growth in years 1, 2 and 3, height, aerial and root dry weight, and root/aerial dry weight ratio), after implementation of SL and SP. The index is expressed as:

$\mathrm{RII}=\left(\mathrm{P}_{\mathrm{w}}-\mathrm{P}_{\mathrm{o}}\right) /\left(\mathrm{P}_{\mathrm{w}}+\mathrm{P}_{\mathrm{o}}\right)$, where $\mathrm{P}_{\mathrm{w}}$ and $\mathrm{P}_{\mathrm{o}}$ are the values of seedling performance under shrubs and in open areas, respectively. Index values higher than 0 indicate facilitative interactions, whereas lower than 0 indicate competitive interactions.

\section{Results}

\subsection{Seedling recruitment and development}

The number of pine seedlings and the frequency of seedling occurrence per stand were significantly higher in SL than in SE stands (average density of 3.6 and 0.6 seedlings $\mathrm{m}^{-2}$, respectively; Supplementary Material) (Table 2, Fig. 3); while no differences were detected over time, except for a decrease in the number of seedlings 25 months after the 2012 fire. Seedling frequency was significantly negatively related (i.e., negative estimated model coefficient) to the percentage cover of $P$. tridentatum after fire (mean \pm Std.Error $=7.1 \pm 1.0 \%$ and $33.7 \pm 2.4 \%$ at SL and SE stands, respectively; Supplementary Material) (Table 3).

We found no significant differences between post-fire treatments for the average seedling height and the percentage of seedling cover in

Table 2

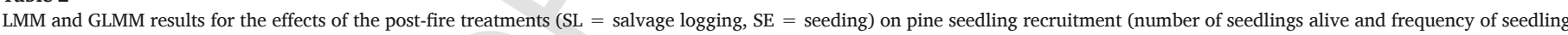

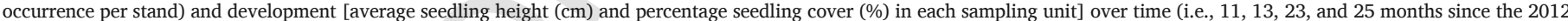

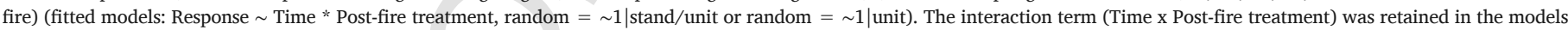
only when significant. The intercept represents the factor levels SL and Time11. Significant p-values are in bold face.

\begin{tabular}{|c|c|c|c|c|c|c|c|c|c|}
\hline & & Intercept & Time13 & Time23 & Time25 & SE & Time13:SE & Time23:SE & Time25:SE \\
\hline \multirow{3}{*}{$\begin{array}{l}\text { Number of pine } \\
\text { seedlings }\end{array}$} & Estimate & 3.279 & -0.067 & -0.063 & -0.281 & -1.510 & & & \\
\hline & Std.Error & 0.355 & 0.093 & 0.093 & 0.099 & 0.503 & & & \\
\hline & $\mathrm{p}$-value & $<0.001$ & 0.477 & 0.502 & 0.008 & 0.013 & & & \\
\hline \multirow{3}{*}{$\begin{array}{l}\text { Pine seedling } \\
\text { frequency }\end{array}$} & Estimate & 1.837 & 0.107 & 0.078 & -0.033 & -0.575 & & & \\
\hline & Std.Error & 0.165 & 0.093 & 0.094 & 0.096 & 0.221 & & & \\
\hline & p-value & $<0.001$ & 0.259 & 0.414 & 0.736 & 0.027 & & & \\
\hline \multirow{3}{*}{$\begin{array}{l}\text { Average pine } \\
\text { seedling height }\end{array}$} & Estimate & 6.425 & 2.756 & 11.093 & 19.303 & -2.893 & & & \\
\hline & Std.Error & 2.053 & 1.252 & 1.278 & 1.309 & 2.759 & & & \\
\hline & $\mathrm{p}$-value & 0.002 & 0.029 & $<0.001$ & $<0.001$ & 0.319 & & & \\
\hline \multirow{3}{*}{$\begin{array}{l}\text { Pine seedling } \\
\text { percentage cover }\end{array}$} & Estimate & 1.202 & 0.491 & 0.832 & 1.212 & -0.236 & -0.142 & -0.691 & -0.417 \\
\hline & Std.Error & 0.147 & 0.106 & 0.102 & 0.096 & 0.242 & 0.212 & 0.219 & 0.208 \\
\hline & p-value & $<0.001$ & $<0.001$ & $<0.001$ & $<0.001$ & 0.353 & 0.505 & 0.002 & 0.046 \\
\hline
\end{tabular}



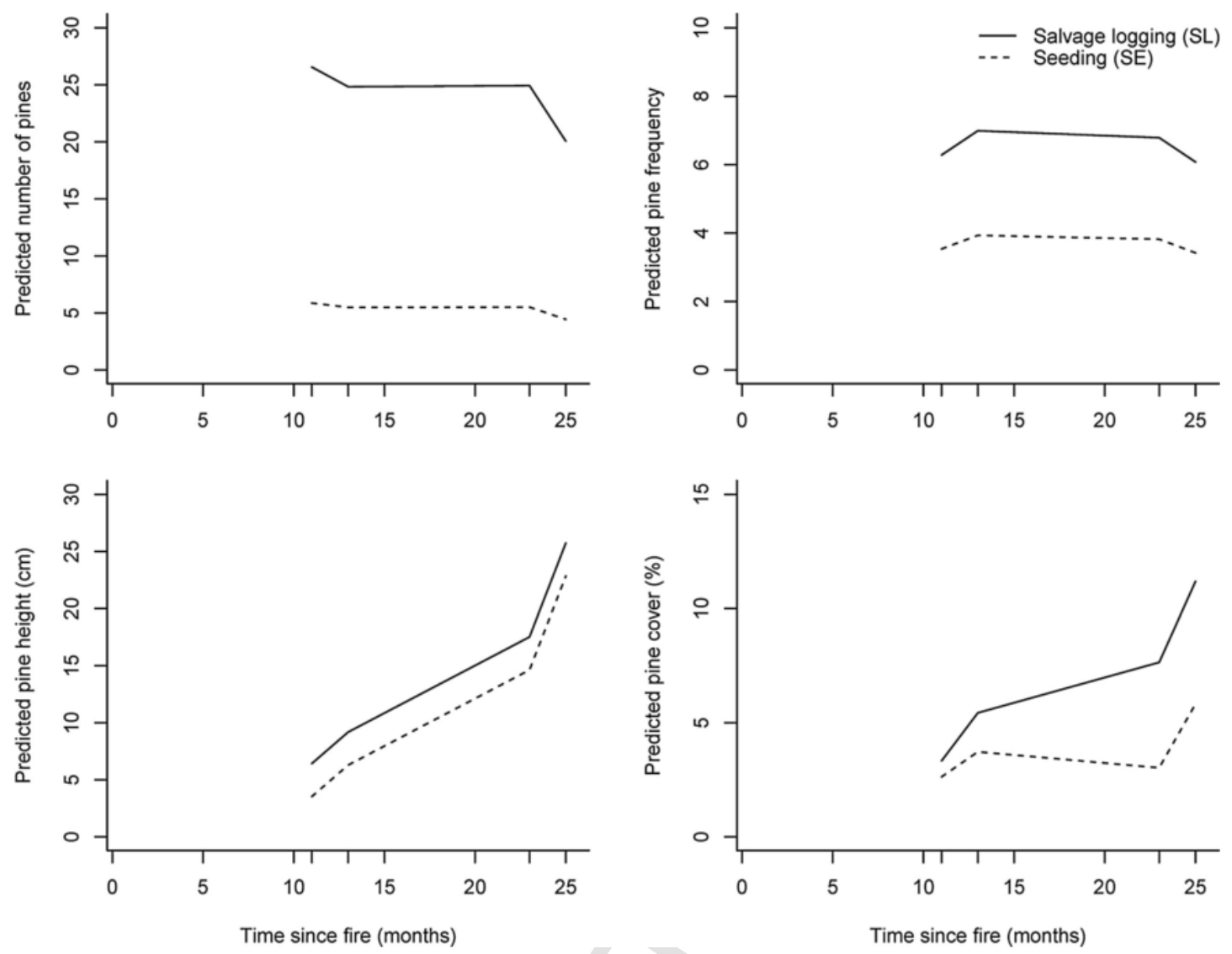

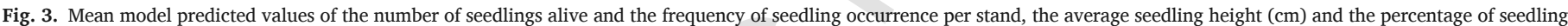
cover (\%) in each sampling unit at stands where salvage logging (SL) and seeding (SE) were applied after the 2012 fire.

Table 3

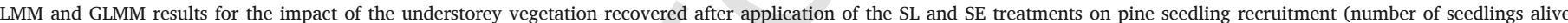

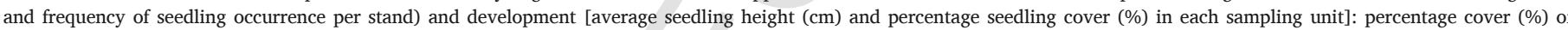

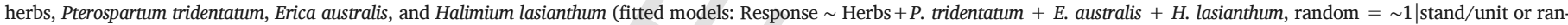
dom $=\sim 1$ |unit). Significant p-values are in bold face.

\begin{tabular}{|c|c|c|c|c|c|c|}
\hline & & Intercept & Herbs & P. tridentatum & E. australis & H. lasianthum \\
\hline \multirow[t]{3}{*}{ Number of pine seedlings } & Estimate & 2.814 & -0.003 & -0.014 & -0.006 & $<-0.001$ \\
\hline & Std.Error & 0.361 & 0.003 & 0.012 & 0.011 & 0.005 \\
\hline & p-value & $<0.001$ & 0.225 & 0.259 & 0.575 & 0.950 \\
\hline \multirow[t]{3}{*}{ Pine seedling frequency } & Estimate & 1.895 & 0.001 & -0.019 & 0.003 & 0.002 \\
\hline & Std.Error & 0.156 & 0.003 & 0.006 & 0.008 & 0.005 \\
\hline & p-value & $<0.001$ & 0.746 & 0.007 & 0.712 & 0.708 \\
\hline \multirow[t]{3}{*}{ Average pine seedling height } & Estimate & 4.215 & 0.202 & 0.091 & 0.108 & 0.224 \\
\hline & Std.Error & 2.202 & 0.040 & 0.048 & 0.049 & 0.036 \\
\hline & p-value & 0.057 & $<0.001$ & 0.063 & 0.030 & $<0.001$ \\
\hline \multirow[t]{3}{*}{ Pine seedling percentage cover } & Estimate & 1.175 & 0.009 & 0.006 & 0.007 & 0.010 \\
\hline & Std.Error & 0.175 & 0.002 & 0.004 & 0.003 & 0.002 \\
\hline & p-value & $<0.001$ & $<0.001$ & 0.115 & 0.051 & $<0.001$ \\
\hline
\end{tabular}

each sampling unit (Table 2, Fig. 3); but there were statistically significant differences among sampling dates with greater values recorded over time, especially 25 months after the 2012 fire, when seedlings start to exhibit exponential growth. Average pine seedling height and cover were significantly positively related (i.e., positive estimated model coefficients) to the percentage cover of herbs $(8.0 \pm 2.9 \%$ and $10.7 \pm 2.6 \%$ at SL and SE stands, respectively; Supplementary Material) and $H$. lasianthum (11.8 $\pm 2.6 \%$ and $22.3 \pm 2.7 \%$ at SL and SE stands, respectively; Supplementary Material) after fire (Table 3). Average height was also significantly positively associated to the per- centage cover of $E$. australis after fire $(8.3 \pm 1.2 \%$ and $11.3 \pm 1.5 \%$ at SL and SE stands, respectively; Supplementary Material).

\subsection{Seedling annual growth and biomass}

Seedling growth in years 1 and 2 and height significantly differed among post-fire treatments with lowest values at the troughs of SP strips where vegetation cover was eliminated prior to planting of seedlings (Table 4, Fig. 4); but there were no differences among post-fire treatments for seedling growth in year 3. Moreover, height was significantly higher under shrub canopy at both SL and SP stands, compared to open spaces. Aerial and root dry weight were significantly 
Table 4

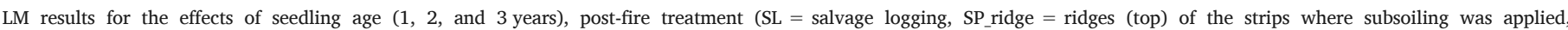

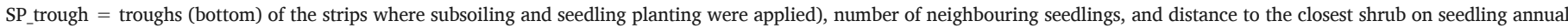

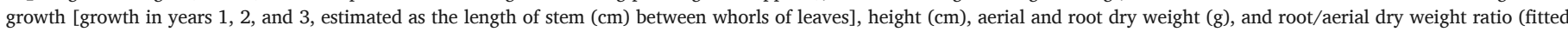
models: Response $\sim$ Pine age + Post-fire treatment + Number of neighbouring pines + Distance to shrub). Df $=$ degrees of freedom. Significant p-values are in bold face.

\begin{tabular}{|c|c|c|c|c|c|}
\hline & & Df & Sum of squares & F value & p-value \\
\hline \multirow[t]{5}{*}{ Growth year 1} & Pine age & 1 & 39.79 & 1.24 & 0.272 \\
\hline & Post-fire treatment & 2 & 317.43 & 4.93 & 0.011 \\
\hline & Number of neighbouring pines & 1 & 50.28 & 1.56 & 0.217 \\
\hline & Distance to shrub & 1 & 20.01 & 0.62 & 0.434 \\
\hline & Residuals & 48 & 1544.49 & & \\
\hline \multirow[t]{5}{*}{ Growth year 2} & Pine age & 1 & 462.96 & 7.57 & $<0.001$ \\
\hline & Post-fire treatment & 2 & 1629.00 & 13.32 & $<0.001$ \\
\hline & Number of neighbouring pines & 1 & 19.09 & 0.31 & 0.579 \\
\hline & Distance to shrub & 1 & 134.22 & 2.20 & 0.145 \\
\hline & Residuals & 48 & 2934.18 & & \\
\hline \multirow[t]{5}{*}{ Growth year 3} & Pine age & 1 & 3071.83 & 128.30 & $<0.001$ \\
\hline & Post-fire treatment & 2 & 35.61 & 0.74 & 0.481 \\
\hline & Number of neighbouring pines & 1 & 0.81 & 0.03 & 0.854 \\
\hline & Distance to shrub & 1 & 3.52 & 0.15 & 0.703 \\
\hline & Residuals & 48 & 1149.24 & & \\
\hline \multirow[t]{5}{*}{ Height } & Pine age & 1 & 761.80 & 10.28 & 0.002 \\
\hline & Post-fire treatment & 2 & 2567.60 & 17.33 & $<0.001$ \\
\hline & Number of neighbouring pines & 1 & 13.10 & 0.18 & 0.676 \\
\hline & Distance to shrub & 1 & 321.70 & 4.34 & 0.043 \\
\hline & Residuals & 48 & 3555.30 & & \\
\hline \multirow{5}{*}{ Aerial dry weight } & Pine age & 1 & 9412.50 & 15.98 & $<0.001$ \\
\hline & Post-fire treatment & 2 & 16902.40 & 14.35 & $<0.001$ \\
\hline & Number of neighbouring pines & 1 & 1624.10 & 2.76 & 0.103 \\
\hline & Distance to shrub & 1 & 1261.60 & 2.14 & 0.150 \\
\hline & Residuals & 48 & 28266.50 & & \\
\hline \multirow[t]{5}{*}{ Root dry weight } & Pine age & 1 & 85.10 & 18.09 & $<0.001$ \\
\hline & Post-fire treatment & 2 & 118.27 & 12.57 & $<0.001$ \\
\hline & Number of neighbouring pines & 1 & 21.83 & 4.64 & 0.036 \\
\hline & Distance to shrub & 1 & 23.24 & 4.94 & 0.031 \\
\hline & Residuals & 48 & 225.80 & & \\
\hline \multirow[t]{5}{*}{ Ratio root/aerial dry weight } & Pine age & 1 & 0.02 & 8.75 & 0.005 \\
\hline & Post-fire treatment & 2 & 0.16 & 29.51 & $<0.001$ \\
\hline & Number of neighbouring pines & 1 & 0.00 & 0.47 & 0.498 \\
\hline & Distance to shrub & 1 & 0.00 & 1.30 & 0.260 \\
\hline & Residuals & 48 & 0.13 & & \\
\hline
\end{tabular}
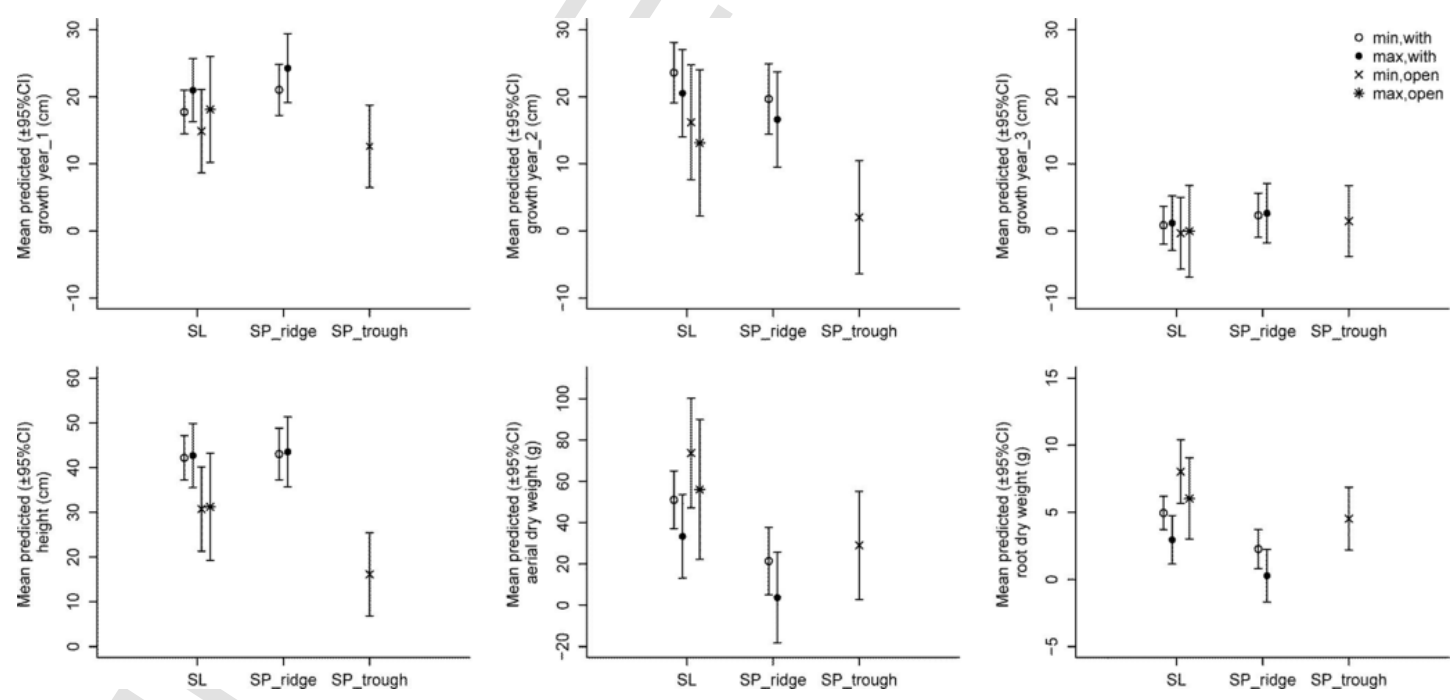

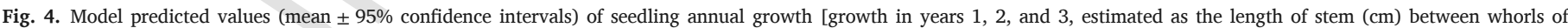

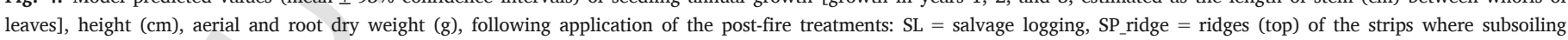

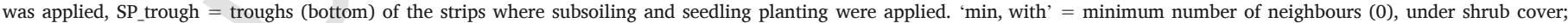

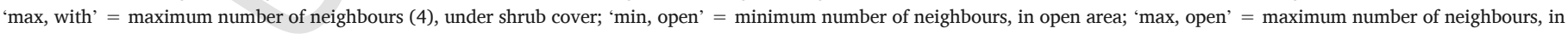
open area. 
greater at SL than at SP stands (Table 4, Fig. 4); while the root/aerial dry weight ratio was significantly higher at the troughs of SP strips (Table 4, Fig. 5). Also, the highest aerial and root dry weight values, as well as the highest root/aerial dry weight ratios, were found in open ground and for the minimum number of neighbouring seedlings.

Correspondingly, the analysis of the relationship between pine height and biomass showed that seedlings growing at $>50 \mathrm{~cm}$ from the closest shrub increased in aerial and root dry weight in relation to height (Fig. 6). In addition, the height of seedlings growing at $<50 \mathrm{~cm}$ from the closest shrub was positively related to shrub diameter, consistently so for the three shrub species tested (Table 5).

The RII values showed that the net outcomes of pine seedling-shrub interactions depended on the performance variables considered (Fig.

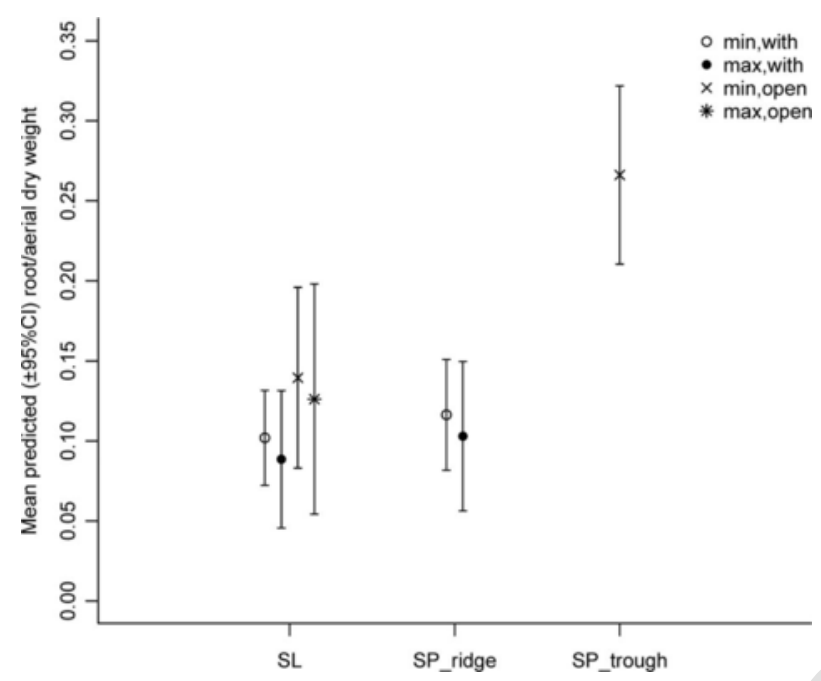

Fig. 5. Model predicted values (mean $\pm 95 \%$ confidence intervals) of the ratio between pine seedling root and aerial dry weight, following application of the post-fire treatments: SL = salvage logging, SP_ridge = ridges (top) of the strips where subsoiling was applied, SP_trough = troughs (bottom) of the strips where subsoiling and seedling planting were applied. 'min, with' = minimum number of neighbours $(0)$, under shrub cover; 'max, with' = maximum number of neighbours (4), under shrub cover; 'min, open' = minimum number of neighbours, in open area; 'max, open' = maximum number of neighbours, in open area.
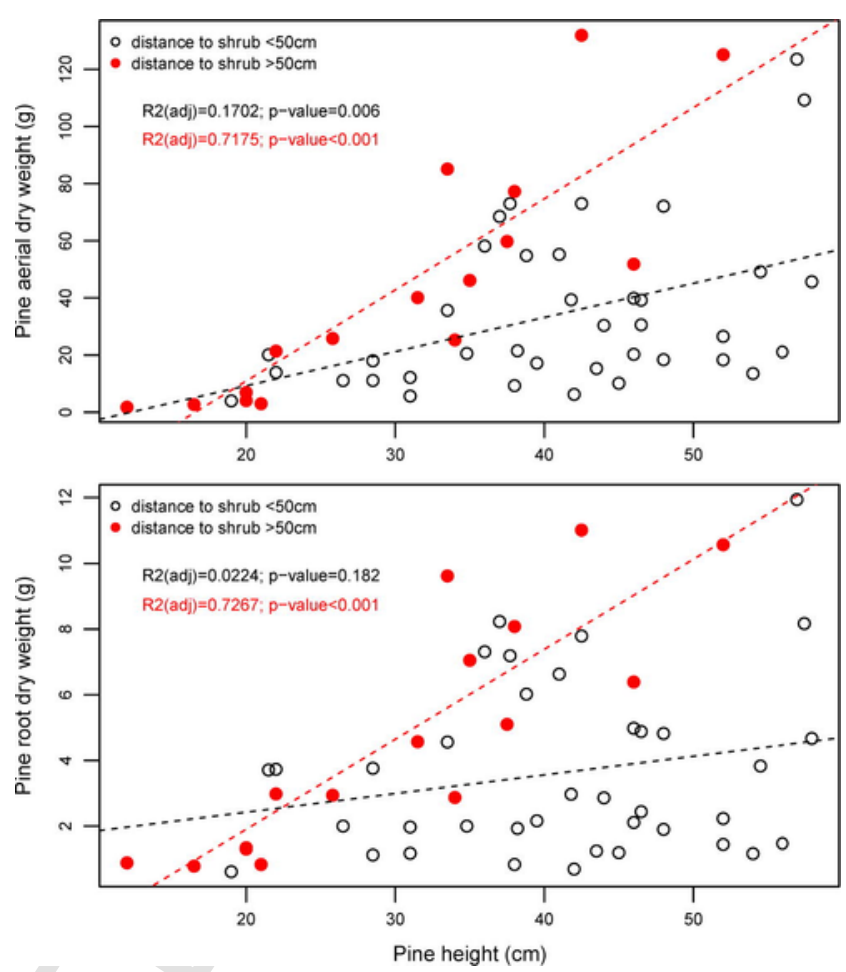

Fig. 6. Regression lines representing the linear relationships between height (cm) and aerial and root dry weight (g) for pine seedlings growing at $<50 \mathrm{~cm}$ (black open circles) and at $>50 \mathrm{~cm}$ (red filled circles) from the closest shrub. R2(adj) = adjusted $\mathrm{R}^{2}$ value. (For interpretation of the references to color in this figure legend, the reader is referred to the web version of this article.)

7). Facilitation (RII $>0$ ) prevailed for annual growth (particularly in year 3 at SL stands and year 2 at SP stands) and height (mostly at SP stands); meanwhile competition (RII $<0$ ) predominated for aerial and root dry weight, and the root/aerial dry weight ratio. Also, neighbouring seedlings increased competition for aerial and root dry weight, especially at the ridges of SP strips, but not for the root/aerial dry weight ratio.

Table 5

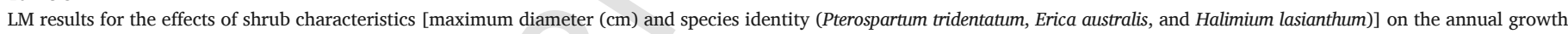

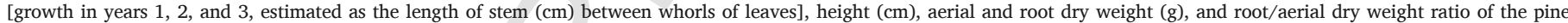

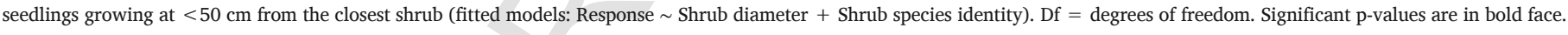

\begin{tabular}{|c|c|c|c|c|c|}
\hline & & $\mathrm{Df}$ & Sum of squares & F value & $\mathrm{p}$ value \\
\hline \multirow[t]{3}{*}{ Growth year 1} & Shrub diameter & 1 & 113.64 & 2.81 & 0.106 \\
\hline & Shrub species & 2 & 42.76 & 0.53 & 0.596 \\
\hline & Residuals & 27 & 1093.71 & & \\
\hline \multirow[t]{3}{*}{ Growth year 2} & Shrub diameter & 1 & 0.20 & 0.00 & 0.964 \\
\hline & Shrub species & 2 & 198.49 & 1.03 & 0.371 \\
\hline & Residuals & 27 & 2604.96 & & \\
\hline \multirow[t]{3}{*}{ Growth year 3} & Shrub diameter & 1 & 188.21 & 1.95 & 0.174 \\
\hline & Shrub species & 2 & 199.63 & 1.03 & 0.370 \\
\hline & Residuals & 27 & 2608.10 & & \\
\hline \multirow[t]{3}{*}{ Height } & Shrub diameter & 1 & 616.24 & 8.51 & 0.007 \\
\hline & Shrub species & 2 & 47.03 & 0.33 & 0.726 \\
\hline & Residuals & 27 & 1955.33 & & \\
\hline \multirow[t]{3}{*}{ Aerial dry weight } & Shrub diameter & 1 & 2251.90 & 2.81 & 0.105 \\
\hline & Shrub species & 2 & 3173.30 & 1.98 & 0.158 \\
\hline & Residuals & 27 & 21634.30 & & \\
\hline \multirow[t]{3}{*}{ Root dry weight } & Shrub diameter & 1 & 15.72 & 2.09 & 0.160 \\
\hline & Shrub species & 2 & 33.60 & 2.23 & 0.126 \\
\hline & Residuals & 27 & 202.99 & & \\
\hline \multirow[t]{3}{*}{ Ratio root/aerial dry weight } & Shrub diameter & 1 & 0.00 & 1.49 & 0.233 \\
\hline & Shrub species & 2 & 0.00 & 0.06 & 0.941 \\
\hline & Residuals & 27 & 0.02 & & \\
\hline
\end{tabular}



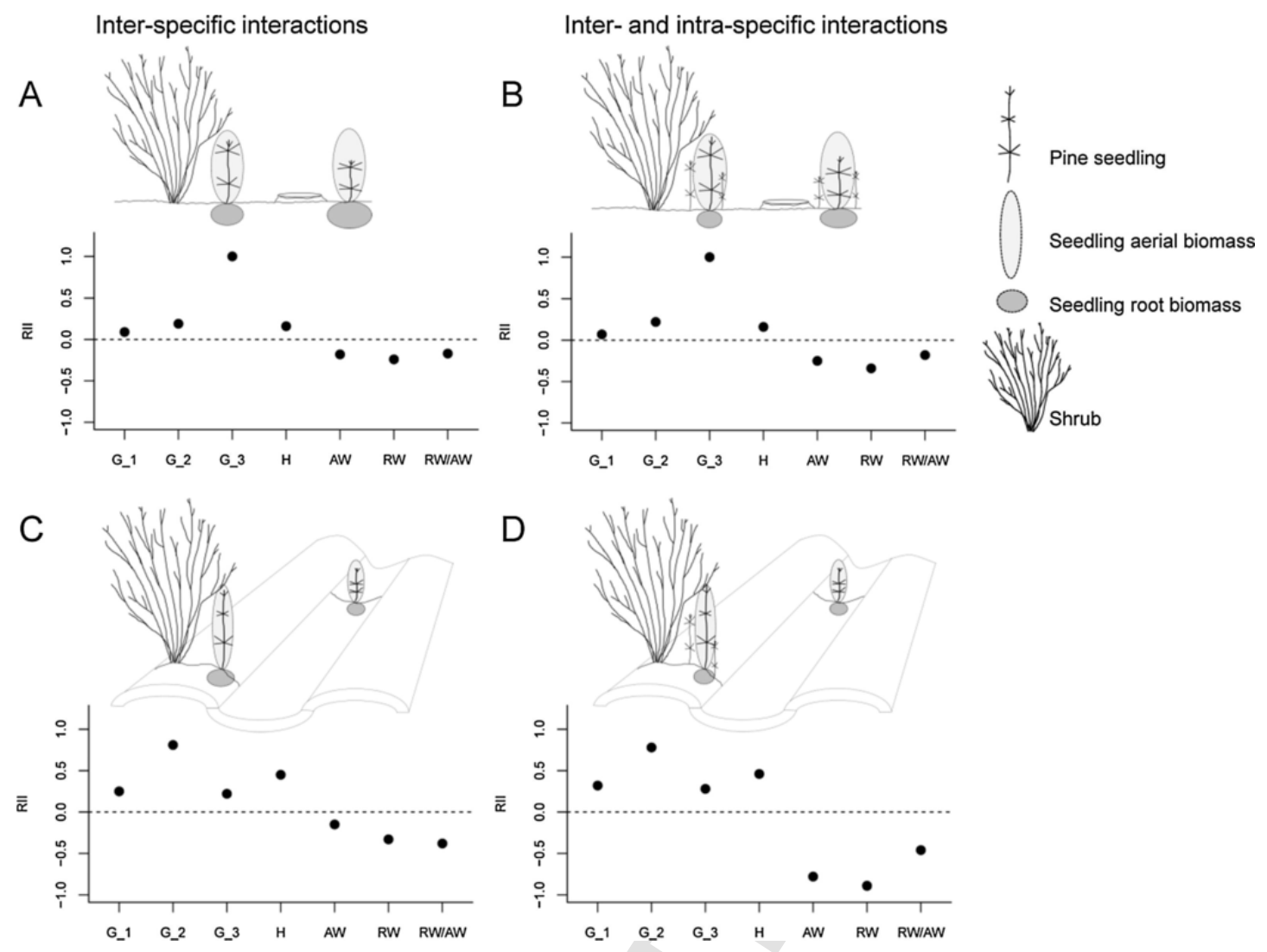

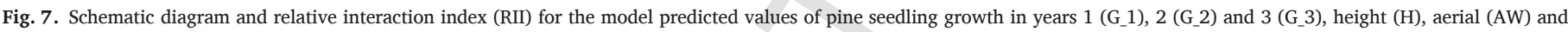

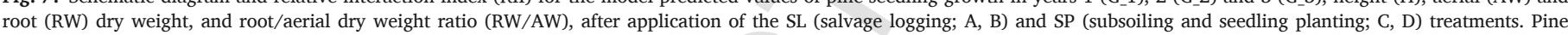

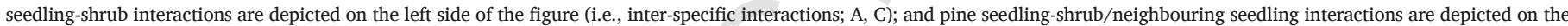

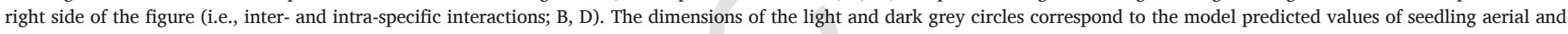
root dry weight in relation to height, respectively. See Figs. 4 and 5 for further details.

\section{Discussion}

Post-fire restoration decisions by forest administrations are largely context-dependent, and usually based on the specific circumstances of the fire, essentially the extension of the burned area, the costs of management operations and the commercial value of the burned wood (Beghin et al., 2010; Leverkus et al., 2012). From a forest manager perspective, rehabilitation after large devastating fires entails urgent stabilisation measures (e.g., mulching, grass seeding, and erosion barrier installation) to reduce flooding, soil loss and sedimentation, and silvicultural treatments (e.g., thinning, shrub removal, and planting of seedlings) to minimise plant competition and restore the cover of the vegetation (Vallejo et al., 2012). There is, however, an ongoing scientific debate about whether, how and when to implement which post-fire restoration action to ensure adequate tree recruitment and fast ecosystem natural regeneration (e.g., controversy over post-fire salvage logging: Beghin et al., 2010; Castro et al., 2011; Fernández et al., 2008; Leverkus et al., 2012, 2014; Lindenmayer and Noss, 2006; Martínez-Sánchez et al., 1999; Rost et al., 2012).

Under the study conditions, the disturbance created by conventional salvage logging after a single large stand-replacing fire had no significant effect on seedling emergence, as sufficient recruitment to obtain adequate natural tree regeneration ( 3.6 seedlings $\mathrm{m}^{-2}$; see Calvo et al., 2008; Fernández et al., 2008; Gil et al., 2009; Martínez-Sánchez et al., 1999; Rodríguez-García et al., 2010) was guaranteed by the plentiful storage of viable seeds (seed viability $>95 \%$ in the studied population; Calvo et al., 2016) inside serotinous cones in the aerial seed bank during the previous fire-free interval (see Tapias et al., 2004; Vega et al., 2008). The massive discharge of seeds triggered by heat most likely prompted the rapid post-fire establishment of seedlings (Hernández-Serrano et al., 2013) that were either very abundant to counterbalance mortality (Martínez-Sánchez et al., 1999) or not seriously harmed by harvesting operations, since trunks were manually dragged and piled avoiding the use of heavy machinery (see Castro et al., 2011 and references therein). Moreover, the 1.5-year delay in undertaking dead wood extraction across the vast burned area may have allowed seedlings to grow and increase resistance to disturbance (i.e., trampling, tree felling, and dragging) damage (see Fernández et al., 2008), while profiting from the facilitative effects of the standing burned trees (Castro et al., 2011; Marañón-Jiménez et al., 2013). Average seedling density at the studied salvaged stands (3.6 seedlings $\mathrm{m}^{-2}$, pre-treatment average tree density $=906$ individuals ha $^{-1}$ ) was clearly higher than that at experimental plots where non-intervention (0.1 seedlings $\mathrm{m}^{-2}$, pre-treatment average tree density $=1304$ individuals $\mathrm{ha}^{-1}$ ), partial cutting of dead trees leaving the biomass in situ ( 0.6 seedlings $\mathrm{m}^{-2}$, pre-treatment average tree density $=1236$ individuals $\left.\mathrm{ha}^{-1}\right)$, and mechanical salvage logging $\left(0.1\right.$ seedlings $\mathrm{m}^{-2}$, pre-treatment average tree density $=1316$ individuals ha ${ }^{-1}$ ) were implemented at a 50-year-old maritime pine reforested stand after a single fire of ca. 1300 ha (Castro et al., 2011). This could be due to the high percentage of maritime pine trees bearing serotinous cones in the studied population (comparatively higher than other populations from northern and southern Spain; Tapias et al., 2004), which very likely provided effective seed mechanical and thermal defence in the course of a high-severity fire (Fernandes and Rigolot, 2007). More research is, 
hence, needed to assess how differences in the application of salvage logging after large stand-replacing fires may influence its ecological impact at the population level (i.e., the serotiny level) on tree regeneration success (de las Heras et al., 2012; Gil et al., 2009), and the full cost-benefit output of restoration operations, relative to other suitable post-fire management alternatives (e.g., no action; see discussion in Leverkus et al., 2012).

Where two large high-severity fires occurred in less than a 14-year period in the study site, seedling recruitment was, comparatively, reduced ( 0.6 seedlings $\mathrm{m}^{-2}$, pre-treatment average tree density $=12,778$ individuals $\mathrm{ha}^{-1}$ ). Fire repetition with a short return interval seems to be the main factor driving the observed low seedling recruitment, as a high number of naturally recruited seedlings was recorded in this area during the first, second and third year (Calvo et al., 2008), and up to five years (Calvo et al., 2013) after the 1998 fire, indicating an adequate natural regeneration of the species after a single fire event. Fire return intervals of less than 15 years imply less number of trees reaching reproductive maturity, and therefore, lower cone production, a smaller canopy seed bank, and less viable seed rain after fire (Espelta et al., 2008; Eugenio et al., 2006; Pausas et al., 2008; Tapias et al., 2001). The lessened seedling recruitment after two fire events in our study site was not fully compensated by the manual spreading of seeds after fire, as most scattered seeds following contour lines were dragged by rainfall towards the bottom of the slopes (personal observation) (see e.g., Espelta et al., 2003). Many additional factors might have also contributed to weaken the effectiveness of direct seeding and to impede seedling establishment, such as post-dispersal seed predation (Ruano et al., 2015), the high percentage of the surface covered by stones and the low coverage of fine woody debris [i.e., downed branches and pieces of dead wood $<2 \mathrm{~cm}$ diameter, and remaining unburned foliage; $7.95 \pm 10.14$ and $0.49 \pm 0.45$ at stands subjected to one and two fires, respectively; unpublished data] (Madrigal et al., 2005; Rodríguez et al., 2008; Rodríguez-García et al., 2010). Yet, in these stands subjected to repeated large fires, average seedling density was either similar or superior to that at the abovementioned experimental plots where burned wood was removed or fully/partly left onsite (Castro et al., 2011), and may be sufficient to ensure post-fire regeneration (Gil et al., 2009). Despite seeding failure, leaving all immature burned trees without commercial value in place may have enhanced natural seedling recruitment to a certain degree via facilitative interactions (through microclimate amelioration), as demonstrated by other authors (Castro et al., 2011; Marzano et al., 2013). Also, many young tree individuals presented early fructification as shortly as four years after fire (personal observation) possibly displaying an adaptive response to recurrent fires (Fernandes and Rigolot, 2007; Tapias et al., 2001, 2004) and helping natural seedling recruitment.

All in all, the frequency of occurrence of large high-severity fires in the study site (i.e., a single or two fires) was decisive in conditioning initial seedling recruitment and establishment, and somehow prevailed over the expected impact of the following management operations on seedling recruitment (both the negative effects of salvage logging and the positive effects of seeding).

In accordance with previous studies (Keeley, 1986; Pausas and Vallejo, 1999; Valdecantos et al., 2008), fire recurrence greatly altered plant dominance in the managed stands, promoting pioneer shrub species with diverse post-fire regeneration strategies: obligate seeder species with slow post-fire recovery (Pausas and Vallejo, 1999) dominated after a single large high-severity fire, whereas resprouter species with fast post-fire regeneration (Keeley, 1986; Pausas and Vallejo, 1999; Valdecantos et al., 2008) dominated after repeated fires. These changes in shrub species composition together with the different handling methods of potential nurse objects by post-fire management operations (i.e., elimination of dead wood by salvage logging, and preservation of immature burned trees by linear subsoiling at the ridges of the stripes) influenced seedling-shrub interactions and, thus, seedling performance. In salvaged stands subjected to one large fire and burned wood removal, the highest positive effect of obligate seeder shrubs (mainly H. lasianthum) was on seedling growth in the third growing season after fire, while their highest negative effect was on root biomass. Similarly, in subsoiled stands following two large fires, the highest positive effect of resprouter shrubs ( $P$. tridentatum and $E$. australis) was on seedling growth in the second growing season after fire and total height, while their highest negative effect was on root biomass, and, to a minor degree, on aerial biomass. In all managed stands, greater annual seedling growth and height under shrubs than in open ground resulted in lower aerial and root biomass, thus, indicating elongation in response to shade, and net aboveground plant competition for light (Calvo et al., 2008 and references therein), as well as belowground competition for water and nutrients at the initial stages of post-fire seedling establishment (Gavinet et al., 2016; Maestre and Cortina, 2004; Prévosto et al., 2012). Better or worse performance of maritime pine seedlings under canopy cover than in open ground at early stages of development has been associated to differences in local climate (Fernandes et al., 2017; Rodríguez-García et al., 2010; Ruano et al., 2009), stand environmental characteristics (Rodríguez-García et al., 2010, 2011), and population-specific life-history strategies (Rodríguez-García and Bravo, 2013; Vizcaíno et al., 2014). In our studied population adapted to dry environments and low nutrient availability, the increased soil fertility (i.e., resource availability) immediately after fire (see Calvo et al., 2008) most likely created a milder environment and resulted in better seedling performance in open ground than under canopy cover (Fernandes et al., 2017; Rodríguez-García and Bravo, 2013; Vizcaíno et al., 2014). To a certain degree, these improved abiotic conditions (i.e., enhanced soil nutrients) amended the environmental stress caused by the high-severity fires, shifting the net balance of plant interactions from positive (facilitation) to negative (competition) (Prévosto et al., 2012; Pugnaire and Luque, 2001; Wright et al., 2014). What is more, competition was aggravated by the presence of neighbouring seedlings (see Gómez-Aparicio, 2009; Prévosto et al., 2012), particularly for aerial and root biomass in subsoiled stands. The negative interactions between naturally recruited seedlings and shrubs (inter-specific competition)/neighbouring seedlings (intra-specific competition) were strengthened at the ridges of strips in subsoiled stands, where (1) resprouter shrubs were promoted by fire recurrence, (2) seedlings developed naturally under shrubs in narrow fringes of vegetation bounded by ploughed soil, and (3) standing immature burned trees were left onsite, most likely contributing to microclimate amelioration. As compared to naturally recruited seedlings at the ridges of the strips, planted seedlings at the troughs were not benefited by mechanical site preparation and plant cover elimination (see Löf et al., 2012) and allocated more biomass to roots (i.e., higher values of the root/aerial dry weight ratio).

These findings, therefore, imply that additional management measures (i.e., a new specific local management scheme) should be undertaken to counteract the negative effects of plant competition on seedling performance after large high-severity fires, especially where very frequent with short between-fire intervals (de las Heras et al., 2012; Moreira et al., 2012). When the main restoration goal is fast recovery of the pre-fire vegetation following large stand-replacing fires, as in the study site, we, thus, recommend:

(i) the partial cutting of dead trees as an alternative to salvage logging to retain some snags that favour seedling growth avoiding belowground competition (Castro et al., 2011), where a sufficient number of seedlings is naturally recruited after one large fire (i.e., no action is the best option since planting or seeding are unneces- 
sary; de las Heras et al., 2012; Moreira et al., 2012) and local inhabitants demand compensatory burned timber selling;

(ii) direct seeding to mimic massive seed rain immediately after fire, leaving unprofitable immature burned trees in place to act as potential nurses buffering microclimate conditions (Castro et al., 2011; Marzano et al., 2013) and enhancing soil fertility (Marañón-Jiménez and Castro, 2013), instead of subsoiling and planting of seedlings (relatively expensive compared to direct seeding; Moreira et al., 2012), where recruitment is undermined by frequent large fires and slopes are smooth (i.e., active restoration with seeds originating from nearby stands with the same serotiny level; de las Heras et al., 2012; Gil et al., 2009); in this case, increasing the amount of fine woody debris prior to seeding could aid the protection of seeds from predation and adverse climate (Madrigal et al., 2005; Rodríguez et al., 2008; Rodríguez-García et al., 2010); and

(iii) either nurse-based planting of seedlings in manually-dug holes close to standing immature burned trees (i.e., active restoration with seedlings grown from seeds collected in nearby stands; de las Heras et al., 2012) or alternately allowing natural succession to resprouter-dominated shrublands highly-adapted to recurrent fires (i.e., forest conversion to an alternative successional stage; Gavinet et al., 2016; Moreira et al., 2012), rather than seeding, where recruitment is lessened by repeated fires and slopes are steep and stony.

Next to the suggested post-fire management operations, we further endorse the application of ecologically-sound fuel reduction treatments planned at the landscape scale (Dunn and Bailey, 2015; Finney et al., 2007; Lehmkuhl et al., 2007; Loehle, 2004) to decrease plant (pioneer shrubs and tree seedlings) competition and the amount of aboveground biomass available for the next fire (see de las Heras et al., 2012; Moreira et al., 2012; Pausas and Paula, 2012). Fuel reduction should be, however, applied after the third growing season following fire, when pine seedlings grow exponentially and the positive effects of nurse shrubs on seedling height have reached their maximum value (see Calvo et al., 2008). Like in other fire-prone Mediterranean ecosystems under even more frequent and intense fire regimes (Doblas-Miranda et al., 2014; Moreira et al., 2011; Pausas et al., 2008), post-fire fuel management strategies that reduce the risk of wildfires and increase ecosystem resilience to recurrent fires would be essential for achieving rapid post-fire recovery at the lowest cost (Loepfe et al., 2010; Moreira et al., 2011; Vallejo et al., 2012).

\section{Conclusions}

Our study provides empirical evidence of the combined effect of recurrent large high-severity fires and conventional post-fire management practices (salvage logging, direct seeding, and linear subsoiling plus seedling planting) on maritime pine seedling recruitment and growth, and, ultimately, on ecosystem recovery, at early stages of succession. Delayed salvage logging of burned trees that were manually dragged had no significant effect on pine seedling establishment after a single large fire event. Two subsequent large stand-replacing fires with short return interval $(<14$ years) reduced pine seedling recruitment and promoted resprouter shrubs. Post-fire manual seeding did not amend the lessened pine tree recruitment following the two large fires, very likely due to site conditions (e.g., high stone and low fine woody debris coverage). The performance of planted seedlings at the troughs of linear strips was not aided by mechanical site preparation and plant cover elimination, as compared to naturally recruited seedlings at the ridges of the strips. In all managed stands, pine seedlings under shrubs exhibited greater annual growth and height, and lower aerial and root biomass than seedlings in open ground, indicating net competition for resources. Competition between naturally recruited pine seedlings and shrubs (inter-specific competition) was strengthened by the occurrence of neighbouring seedlings (intra-specific competition) and by mechanical site preparation prior to planting of seedlings. Overall, the recurrence of large fires influenced initial pine seedling establishment, and prevailed over the impact of the following management operations. These findings, hence, entail that alternative management measures should be undertaken to improve pine seedling recruitment and counteract the negative effects of plant competition on seedling performance after large high-severity fires, especially where very frequent with short between-fire intervals, and when the main restoration goal is the fast recovery of the pre-fire vegetation.

\section{Acknowledgements}

We thank the Environmental Department of the Regional Government of Castilla and León for the information provided. This work was supported by the Spanish Ministry of Economy and Competitiveness, and the European Regional Development Fund (ESFIRE project, AGL2013-48189-C2-1-R); and the Regional Government of Castilla and León (FIRECYL project, LE033U14).

\section{Appendix A. Supplementary material}

Supplementary data associated with this article can be found, in the online version, at http://dx.doi.org/10.1016/j.foreco.2017.07.029.

\section{References}

Ammer, C., Mosandl, R., 2007. Which grow better under the canopy of Norway spruce planted or sown seedlings of European beech?. Forestry 80, 385-395.

Armas, C., Ordiales, R., Pugnaire, F.I., 2004. Measuring plant interactions: a new comparative index. Ecology 85, 2682-2686.

Baeza, M.J., Valdecantos, A., Alloza, J.A., Vallejo, V.R., 2007. Human disturbance and environmental factors as drivers of long-term post-fire regeneration patterns in Mediterranean forests. J. Veg. Sci. 18, 243-252.

Beghin, R., Lingua, E., Garbarino, M., Lonati, M., Bovio, G., Motta, R., Marzano, R., 2010. Pinus sylvestris forest regeneration under different post-fire restoration practices in the northwestern Italian Alps. Ecol. Eng. 36, 1365-1372.

Bertness, M.D., Callaway, R., 1994. Positive interactions in communities. Trends Ecol. Evol. 9, 191-193.

Brooker, R.W., Maestre, F.T., Callaway, R.M., Lortie, C.L., Cavieres, L.A., Kunstler, G., Liancourt, P., Tielbörger, K., Travis, J.M.J., Anthelme, F., Armas, C., Coll, L., Corcket, E., Delzon, S., Forey, E., Kikvidze, Z., Olofsson, J., Pugnaire, F., Quiroz, C.L., Saccone, P., Schiffers, K., Seifan, M., Touzard, B., Michalet, R., 2008. Facilitation in plant communities: the past, the present, and the future. J. Ecol. 96, 18-34.

Callaway, R.M., Brooker, R.W., Choler, P., Kikvidze, Z., Lortie, C.J., Michalet, R., Paolini, L., Pugnaire, F.I., Newingham, B., Aschehoug, E.T., Armas, C., Kikodze, D., Cook, B.J., 2002. Positive interactions among alpine plants increase with stress. Nature 417, 844-848.

Calvo, L., Baeza, J., Marcos, E., Santana, V., Papanastasis, V.P., 2012. Post-Fire Management of Shrublands. In: Moreira, F., Arianoutsou, M., Corona, P., De las Heras, J. (Eds.), Post-Fire Management and Restoration of Southern European Forests, Managing Forest Ecosystems 24. Springer Science + Business Media B.V., pp. 293-319.

Calvo, L., Hernández, V., Valbuena, L., Taboada, A., 2016. Provenance and seed mass determine seed tolerance to high temperatures associated to forest fires in Pinus pinaster. Ann. For. Sci. 73, 381-391.

Calvo, L., Santalla, S., Valbuena, L., Marcos, E., Tárrega, R., Luis-Calabuig, E., 2008. Post-fire natural regeneration of a Pinus pinaster forest in NW Spain. Plant Ecol. 197, 81-90.

Calvo, L., Torres, O., Valbuena, L., Luis-Calabuig, E., 2013. Recruitment and early growth of Pinus pinaster seedlings over five years after a wildfire in NW Spain. For. Syst. 22, 582-586.

Castro, J., Allen, C.D., Molina-Morales, M., Marañón-Jiménez, S., Sánchez-Miranda, , Zamora, R., 2011. Salvage logging versus the use of burnt wood as a nurse object to promote post-fire tree seedling establishment. Restor. Ecol. 19, 537-544.

Castro, J., Zamora, R., Hódar, J.A., Gómez, J.M., Gómez-Aparicio, L., 2004. Benefits of using shrubs as nurse plants for reforestation in Mediterranean mountains: a 4-year study. Restor. Ecol. 12, 352-358.

De las Heras, J., Moya, D., Vega, J.A., Daskalakou, E., Vallejo, R., Grigoriadis, N., Tsitsoni, T., Baeza, J., Valdecantos, A., Fernández, C., Espelta, J., Fernandes, P., 2012. Post-Fire Management of Serotinous Pine Forests. In: Moreira, F., Arianoutsou, M., Corona, P., De las Heras, J. (Eds.), Post-Fire Management and Restoration of South- 
ern European Forests, Managing Forest Ecosystems 24. Springer Science + Business Media B.V., pp. 121-150.

Doblas-Miranda, E., Martínez-Vilalta, J., Lloret, F., Álvarez, A., Ávila, A., Bonet, F.J., Brotons, L., Castro, J., Curiel Yuste, J., Díaz, M., Ferrandis, P., García-Hurtado, E., Iriondo, J.M., Keenan, T.F., Latron, J., Llusià, J., Loepfe, L., Mayol, M., Moré, G., Moya, D., Peñuelas, J., Pons, X., Poyatos, R., Sardans, J., Sus, O., Vallejo, V.R., Vayreda, J., Retana, J., 2014. Reassessing global change research priorities in Mediterranean terrestrial ecosystems: how far have we come and where do we go from here?. Global Ecol. Biogeogr. 24, 25-43.

Dunn, C.J., Bailey, J.D., 2015. Modeling the direct effects of salvage logging on long-term temporal fuel dynamics in dry-mixed conifer forests. For. Ecol. Manage. 341, 93-109.

Espelta, J.M., Retana, J., Habrouk, A., 2003. An economic and ecological multi-criteria evaluation of reforestation methods to recover burned Pinus nigra forests in NE Spain. For. Ecol. Manage. 180, 185-198.

Espelta, J.M., Verkaik, I., Eugenio, M., Lloret, F., 2008. Recurrent wildfires constrain long-term reproduction ability in Pinus halepensis Mill. Int. J. Wildland Fire 17, 579-585.

Eugenio, M., Verkaik, I., Lloret, F., Espelta, J.M., 2006. Recruitment and growth decline in Pinus halepensis populations after recurrent wildfires in Catalonia (NE Iberian Peninsula). For. Ecol. Manage. 231, 47-54.

Fernandes, P., Máguas, C., Correia, O., 2017. Combined effects of climate, habitat, and disturbance on seedling establishment of Pinus pinaster and Eucalyptus globulus. Plant Ecol. 218, 501-515.

Fernandes, P.M., Rigolot, E., 2007. The fire ecology and management of maritime pine (Pinus pinaster Ait.). For. Ecol. Manage. 241, 1-13.

Fernández, C., Vega, J.A., Fonturbel, T., Jiménez, E., Pérez-Gorostiaga, P., 2008. Effects of wildfire, salvage logging and slash manipulation on Pinus pinaster Ait. recruitment in Orense (NW Spain). For. Ecol. Manage. 255, 1294-1304.

Fernández-García, V., Fernández-Manso, A., Quintano, C., Marcos, E., Calvo, L., 2015. Elaboración de mapas de recurrencia de incendios forestales en la Sierra del Teleno utilizando imágenes Landsat (1978-2014). In: Bustamante, J., Díaz-Delgado, R., Aragonés, D., Afán, I., García, D. (Eds.), Teledetección: Humedales y Espacios Protegidos. Proceedings of the XVI Congreso de la Asociación Española de Teledetección, pp. 145-148. < http://www.aet.org.es/?q= congresos > (accessed 07.06.17).

Finney, M.A., Seli, R.C., McHugh, C.W., Ager, A.A., Bahro, B., Agee, J.K., 2007. Simulation of long-term landscape-level fuel treatment effects on large wildfires. Int. J. Wildland Fire 16, 712-727.

Gavinet, J., Prévosto, B., Fernandez, C., 2016. Introducing resprouters to enhance Mediterranean forest resilience: importance of functional traits to select species according to a gradient of pine density. J. Appl. Ecol. 53, 1735-1745.

Gil, L., López, R., García-Mateos, , González-Doncel, I., 2009. Seed provenance and fire-related reproductive traits of Pinus pinaster in central Spain. Int. J. Wildland Fire 18, 1003-1009.

Gómez-Aparicio, L., 2009. The role of plant interactions in the restoration of degraded ecosystems: a meta-analysis across life-forms and ecosystems. J. Ecol. 97, 1202-1214.

Gómez-Aparicio, L., Gómez, J.M., Zamora, R., Boettinger, J.L., 2005. Canopy vs. soil effects of shrubs facilitating tree seedlings in Mediterranean montane ecosystems. J. Veg. Sci. 16, 191-198.

Gómez-Aparicio, L., Zamora, R., Castro, J., Hódar, J.A., 2008. Facilitation of tree saplings by nurse plants: Microhabitat amelioration or protection against herbivores?. J. Veg. Sci. 19, 161-172.

Hernández-Serrano, A., Verdú, M., González-Martínez, S.C., Pausas, J.G., 2013. Fire structures pine serotiny at different scales. Am. J. Bot. 100, 2349-2356.

Keeley, J.E., 1986. Resilience of Mediterranean shrub communities to fires. In: Dell, B., Hopkins, A.J.M., Lamont, B.B. (Eds.), Resilience in Mediterranean-type Ecosystems. Dr W. Junk Publishers, Dordrecht, The Netherlands, pp. 95-112.

Lehmkuhl, J.F., Kennedy, M., Ford, E.D., Singleton, P.H., Gaines, W.L., Lind, R.L., 2007. Seeing the forest for the fuel: Integrating ecological values and fuels management. For. Ecol. Manage. 246, 73-80.

Leverkus, A.B., Lorite, J., Navarro, F.B., Sánchez-Cañete, E.P., Castro, J., 2014. Post-fire salvage logging alters species composition and reduces cover, richness, and diversity in Mediterranean plant communities. J. Environ. Manage. 133, 323-331.

Leverkus, A.B., Puerta-Piñero, C., Guzmán-Álvarez, J.R., Navarro, J., Castro, J., 2012. Post-fire salvage logging increases restoration costs in a Mediterranean mountain ecosystem. New Forest. 43, 601-613.

Lindenmayer, D.B., Noss, R.F., 2006. Salvage logging, ecosystem processes, and biodiversity conservation. Conserv. Biol. 20, 949-958.

Loehle, C., 2004. Applying landscape principles to fire hazard reduction. For. Ecol. Manage. 198, 261-267

Loepfe, L., Martínez-Vilalta, J., Oliveres, J., Piñol, J., Lloret, F., 2010. Feedbacks between fuel reduction and landscape homogenisation determine fire regimes in three Mediterranean areas. For. Ecol. Manage. 259, 2366-2374.

Löf, M., Dey, D.C., Navarro, R.M., Jacobs, D.F., 2012. Mechanical site preparation for forest restoration. New Forest. 43, 825-848.

Madrigal, J., Hernando, C., Martínez, E., Guijarro, M., Díez, C., 2005. Regeneración post-incendio de Pinus pinaster Ait. en la Sierra de Guadarrama (Sistema Central, España): modelos descriptivos de los factores influyentes en la densidad inicial y la supervivencia. Invest. Agrar.: Sist. Recur. For. 14, 36-51.

Maestre, F.T., Bautista, S., Cortina, J., 2003. Positive, negative, and net effects in grass-shrub interactions in Mediterranean semiarid grasslands. Ecology 84, 3186-3197.
Maestre, F.T., Callaway, R.M., Valladares, F., Lortie, C.J., 2009. Refining the stress-gradient hypothesis for competition and facilitation in plant communities. J. Ecol. 97 199-205.

Maestre, F.T., Cortina, J., 2004. Do positive interactions increase with abiotic stress? A test from a semi-arid steppe. P. Roy. Soc. Lond. B Bio. 271, S331-S333.

Maestre, F.T., Valladares, F., Reynolds, J.F., 2005. Is the change of plant-plant interactions with abiotic stress predictable? A meta-analysis of field results in arid environments. J. Ecol. 93, 748-757.

Marañón-Jiménez, S., Castro, J., 2013. Effect of decomposing post-fire coarse woody debris on soil fertility and nutrient availability in a Mediterranean ecosystem. Biogeochemistry $112,519-535$

Marañón-Jiménez, S., Castro, J., Querejeta, J.I., Fernández-Ondoño, E., Allen, C.D., 2013. Post-fire wood management alters water stress, growth, and performance of pine regeneration in a Mediterranean ecosystem. For. Ecol. Manage. 308, 231-239.

Martínez-Sánchez, J.J., Ferrandis, P., De las Heras, J., Herranz, J.M., 1999. Effect of burnt wood removal on the natural regeneration of Pinus halepensis after fire in a pine forest in Tus valley (SE Spain). For. Ecol. Manage. 123, 1-10.

Marzano, R., Garbarino, M., Marcolin, E., Pividori, M., Lingua, E., 2013. Deadwood anisotropic facilitation on seedling establishment after a stand-replacing wildfire in Aosta Valley (NW Italy). Ecol. Eng. 51, 117-122.

Moreira, F., Arianouotsou, M., Vallejo, V.R., de las Heras, J., Corona, P., Xanthopoulos, G., Fernandes, P., Papageorgiou, K., 2012. Setting the Scene for Post-Fire Management. In: Moreira, F., Arianoutsou, M., Corona, P., De las Heras, J. (Eds.), Post-Fire Management and Restoration of Southern European Forests, Managing Forest Ecosystems 24. Springer Science + Business Media B.V., pp. 1-19.

Moreira, F., Catry, F., Lopes, T., Bugalho, M.N., Rego, F., 2009. Comparing survival and size of resprouts and planted trees for post-fire forest restoration in central Portugal. Ecol. Eng. 35, 870-873.

Moreira, F., Viedma, O., Arianoutsou, M., Curt, T., Koutsias, N., Rigolot, E., Barbati, A., Corona, P., Vaz, P., Xanthopoulos, G., Mouillot, F., Bilgili, E., 2011. Landscape-wildfire interactions in southern Europe: Implications for landscape management. J. Environ. Manage. 92, 2389-2402.

Padilla, F.M., Pugnaire, F.I., 2006. The role of nurse plants in the restoration of degraded environments. Front. Ecol. Environ. 4, 196-202.

Pausas, J.G., Fernández-Muñoz, S., 2012. Fire regime changes in the Western Mediterranean Basin: from fuel-limited to drought-driven fire regime. Climatic Change 110 215-226.

Pausas, J.G., Llovet, J., Rodrigo, A., Vallejo, R., 2008. Are wildfires a disaster in the Mediterranean basin? A review. Int. J. Wildland Fire 17, 713-723.

Pausas, J.G., Paula, S., 2012. Fuel shapes the fire-climate relationship: evidence from Mediterranean ecosystems. Global Ecol. Biogeogr. 21, 1074-1082

Pausas, J.G., Vallejo, V.R., 1999. The role of fire in European Mediterranean Ecosystems In: Chuvieco, E. (Ed.), Remote Sensing of Large Wildfires in the European Mediterranean Basin. Springer-Verlag, Berlin, pp. 3-16.

Pinheiro, J., Bates, D., DebRoy, S., Sarkar, D., R Core Team, 2014. nlme: Linear and Non linear Mixed Effects Models. R package version 3.1-118, < http://CRAN.R-project. org $/$ package $=$ nlme $>$

Prévosto, B., Monnier, Y., Ripert, C., Fernandez, C., 2012. To what extent do time, species identity and selected plant response variables influence woody plant interactions?. J. Appl. Ecol. 49, 1344-1355.

Puerta-Piñero, C., Espelta, J.M., Sánchez-Humanes, B., Rodrigo, A., Coll, L., Brotons, L., 2012. History matters: previous land use changes determine post-fire vegetation recovery in forested Mediterranean landscapes. For. Ecol. Manage. 279, 121-127.

Pugnaire, F.I., Luque, M.T., 2001. Changes in plant interactions along a gradient of environmental stress. Oikos 93, 42-49.

Quintano, C., Fernández-Manso, A., Calvo, L., Marcos, E., Valbuena, L., 2015. Land surface temperature as potential indicator of burn severity in forest Mediterranean ecosystems. Int. J. Appl. Earth Obs. 36, 1-12.

Quintano, C., Fernández-Manso, A., Roberts, D.A., 2017. Burn severity mapping from Landsat MESMA fraction images and Land Surface Temperature. Remote Sens. Environ. 190, 83-95.

R Core Team, 2014. R: a language and environment for statistical computing. R Foundation for Statistical Computing, Vienna, Austria, <http://www.R-project.org/ >

Retana, J., Espelta, J.M., Habrouk, A., Ordóñez, J.L., de Solà-Morales, F., 2002. Regeneration patterns of three Mediterranean pines and forest changes after a large wildfire in northeastern Spain. Ecoscience 9, 89-97.

Rodrigo, A., Retana, J., Picó, F.X., 2004. Direct regeneration is not the only response of Mediterranean forests to large fires. Ecology 85, 716-729.

Rodríguez, R.J., Serrada, R., Lucas, J.A., Alejano, R., del Río, M., Torres, E., Cantero, A., 2008. Selvicultura de Pinus pinaster Ait. subsp. mesogeensis Fieschi \& Gaussen. In: Serrada, R., Montero, G., Reque Kilchenmann, J.A. (Eds.), Compendio de Selvicultura aplicada en España. Instituto Nacional de Investigación y Tecnología Agraria y Alimentaria (INIA), Madrid, pp. 399-430.

Rodríguez-García, E., Bravo, F., 2013. Plasticity in Pinus pinaster populations of diverse origins: Comparative seedling responses to light and Nitrogen availability. For. Ecol. Manage. 307, 196-205.

Rodríguez-García, E., Bravo, F., Spies, T.A., 2011. Effects of overstory canopy, plant-plant interactions and soil properties on Mediterranean maritime pine seedling dynamics. For. Ecol. Manage. 262, 244-251.

Rodríguez-García, E., Juez, L., Bravo, F., 2010. Environmental influences on post-harvest natural regeneration of Pinus pinaster Ait. in Mediterranean forest stands submitted to the seed-tree selection method. Eur. J. For. Res. 129, 1119-1128. 
Rost, J., Clavero, M., Brotons, L., Pons, P., 2012. The effect of postfire salvage logging on bird communities in Mediterranean pine forests: the benefits for declining species. J. Appl. Ecol. 49, 644-651.

Ruano, I., del Peso, C., Bravo, F., 2015. Post-dispersal predation of Pinus pinaster Aiton seeds: key factors and effects on belowground seed bank. Eur. J. For. Res. 134, 309-318.

Ruano, I., Pando, V., Bravo, F., 2009. How do light and water influence Pinus pinaster Ait germination and early seedling development?. For. Ecol. Manage. 258, 2647-2653.

Santamaría, J.E., 2015. El pino pinaster de la Sierra del Teleno. Historia, ordenación, crecimiento y producción. $\mathrm{PhD}$ thesis, University of Léon, Spain.

Schöb, C., Armas, C., Guler, M., Prieto, I., Pugnaire, F.I., 2013. Variability in functional traits mediates plant interactions along stress gradients. J. Ecol. 101, 753-762.

Siles, G., Rey, P.J., Alcántara, J.M., 2010. Post-fire restoration of Mediterranean forests: testing assembly rules mediated by facilitation. Basic Appl. Ecol. 11, 422-431.

Siles, G., Rey, P.J., Alcántara, J.M., Ramírez, J.M., 2008. Assessing the long-term contribution of nurse plants to restoration of Mediterranean forests through Markovian models. J. Appl. Ecol. 45, 1790-1798.

Tapias, R., Climent, J., Pardos, J.A., Gil, L., 2004. Life histories of Mediterranean pines. Plant Ecol. 171, 53-68.

Tapias, R., Gil, L., Fuentes-Utrilla, P., Pardos, J.A., 2001. Canopy seed banks in Mediterranean pines of southeastern Spain: a comparison between Pinus halepensis Mill., Pinus pinaster Ait., Pinus nigra Arn. and Pinus pinea L.. J. Ecol. 89, 629-638.

Tewksbury, J.J., Lloyd, J.D., 2001. Positive interactions under nurse-plants: spatial scale, stress gradients and benefactor size. Oecologia 127, 425-434.
Torres, I., Pérez, B., Quesada, J., Viedma, O., Moreno, J.M., 2016. Forest shifts induced by fire and management legacies in a Pinus pinaster woodland. For. Ecol. Manage. 361, 309-317.

Valdecantos, A., Baeza, M.J., Vallejo, V.R., 2008. Vegetation management for promoting ecosystem resilience in fire-prone Mediterranean shrublands. Restor. Ecol. 17, 414-421.

Vallejo, V.R., Arianoutsou, M., Moreira, F., 2012. Fire Ecology and Post-Fire Restoration Approaches in Southern European Forest Types. In: Moreira, F., Arianoutsou, M., Corona, P., De las Heras, J. (Eds.), Post-Fire Management and Restoration of Southern European Forests, Managing Forest Ecosystems 24. Springer Science + Business Media B.V., pp. 93-119.

Vega, J.A., Fernández, C., Pérez-Gorostiaga, P., Fonturbel, T., 2008. The influence of fire severity, serotiny, and post-fire management on Pinus pinaster Ait. recruitment in three burnt areas in Galicia (NW Spain). For. Ecol. Manage. 256, 1596-1603.

Venables, W.N., Ripley, B.D., 2002. Modern Applied Statistics with S, 4th ed. Springer, New York.

Vizcaíno-Palomar, N., Revuelta-Eugercios, B., Zavala, M.A., Alía, R., González-Martínez, S.C., 2014. The role of population origin and microenvironment in seedling emergence and early survival in Mediterranean maritime pine (Pinus pinaster Aiton). PLoS One 9 (10), e109132

Wright, A., Schnitzer, S.A., Reich, P.B., 2014. Living close to your neighbors: the im portance of both competition and facilitation in plant communities. Ecology 95, 2213-2223. 